\title{
"Not the Almighty": Evaluating Aboriginal Influence in Northern Land-Claim Boards
}

\author{
GRAHAM WHITE ${ }^{1}$
}

(Received 26 June 2007; accepted in revised form 17 March 2008)

\begin{abstract}
The settling of comprehensive land claims across Canada's territorial North has brought about substantial changes in governance. Prominent among these has been the establishment of numerous regulatory and co-management boards dealing with land, wildlife, and environmental issues. These boards were explicitly designed to bring significant aboriginal influence to bear in key land and wildlife decisions. To examine whether the boards have enhanced aboriginal participation and influence in these decision-making processes, factors such as the number and influence of aboriginal board members, the extent of board powers, the independence (financial and otherwise) of the boards, and the boards' willingness and capacity to incorporate traditional knowledge into their operations are considered. Overall, the evidence supports the conclusion that the land-claim boards represent an important vehicle for substantially enhanced aboriginal involvement in and influence over government decisions affecting the wildlife and environment of traditional aboriginal lands.
\end{abstract}

Key words: aboriginal, land claims, co-management, environmental regulation, boards

RÉSUMÉ. Le règlement d'importantes revendications territoriales dans les territoires canadiens du Nord s'est traduit par des changements considérables en matière de gouvernance. L'un de ces changements les plus importants a consisté en l'établissement de nombreux conseils de réglementation et de cogestion s'occupant de questions ayant trait aux terres, à la faune et à l'environnement. Ces conseils ont été explicitement conçus pour que les Autochtones exercent une plus grande influence sur les décisions relatives aux terres et à la faune. Afin d'examiner si ces conseils ont permis d'améliorer la participation des Autochtones et de rehausser l'influence qu'ils ont sur la prise de décisions, divers facteurs tels que le nombre et l'influence des membres autochtones aux conseils, l'étendue des pouvoirs des conseils, l'autonomie (financière ou autre) de même que la volonté et la capacité des conseils à intégrer les connaissances traditionnelles à leur exploitation entrent en ligne de compte. Dans l'ensemble, bien des éléments portent à croire que les conseils découlant des revendications territoriales représentent un important véhicule menant à une participation et à une influence autochtones substantiellement accrues à l'égard des décisions gouvernementales concernant la faune et l'environnement des terres autochtones traditionnelles.

Mots clés : autochtone, revendications territoriales, co-gestion, réglementation environnementale, conseils

Traduit pour la revue Arctic par Nicole Giguère.

\section{INTRODUCTION}

Politicians with unpopular records in office, when facing re-election, have been known to implore cranky voters to "compare me with the alternative, not the Almighty." However well such an appeal works as an electoral tactic, it has much to recommend it as a principle for evaluating northern land-claim boards. The various regulatory and co-management boards established under Canada's northern comprehensive land claims clearly represent a major departure in governance, premised as they are on enhancing aboriginal participation in key land and wildlife decisions. But are these new arrangements significant advances for the aboriginal peoples of the North, according them unprecedented influence over issues central to their livelihood and cultural well-being? Or is it the case that, in the words of one critic, "it would be difficult to conceive a more insidious form of cultural assimilation than co-management as currently practiced in northern Canada" (Stevenson, 2004:68)?

This paper evaluates these distinctive institutions that have become so central to a wide range of important policy processes in the North. The evaluation is limited to governance issues, especially the role and influence of aboriginal people in decision-making processes, and does not attempt to determine the appropriateness or the effectiveness of decisions and policies relating to environmental protection or wildlife management. Its empirical base encompasses only boards operating in the territorial North and thus does not consider either the various institutions established up to three decades ago under the James Bay and Northern Quebec Agreement or the boards emerging from the much more recent Labrador Inuit Association claim.

I argue that overall, the land-claim boards constitute a signal improvement for aboriginal people in terms of both their formal involvement in governmental processes and

\footnotetext{
${ }^{1}$ Department of Political Science, University of Toronto at Mississauga, Kaneff Centre, 3359 Mississauga Road North, Mississauga,

Ontario L5L 1C6, Canada; gwhite@ chass.utoronto.ca

(C) The Arctic Institute of North America
} 
consideration of their interests and preferences. In the days when far-reaching decisions were made in Ottawa, most notably by the Department of Indian Affairs and Northern Development (DIAND, now Indian and Northern Affairs Canada, or INAC), and the Department of Fisheries and Oceans (DFO), the processes leading to those decisions rarely accorded aboriginal people anything approaching meaningful involvement.

At the same time, the paper is no uncritical paean to land-claim boards. Individual boards exhibit serious flaws (and some have been painfully dysfunctional), while systematic problems and shortcomings are evident across the entire range of land-claim boards. Among other things, they have been criticized for providing little more than token aboriginal influence over land and wildlife decisions, for remaining (via funding arrangements and appointment provisions) essentially under the control of the federal government (or, less frequently, the territorial governments) and, perhaps most damningly, for undercutting rather than enhancing aboriginal peoples' self-determination and autonomy by enmeshing them in Western modes of thought and behaviour. Critics maintain that aboriginal influence under the board regime falls woefully short of what might be achieved under full-fledged aboriginal self-government.

All these criticisms carry some validity. Clearly, significant room for improvement exists both within individual boards and across the overall board regime. However, much the same could be said of any set of political institutions. Accepting that it would certainly be possible to imagine better ways of ensuring aboriginal influence, or indeed control, over land and wildlife decisions, the question of possible alternatives to land-claim boards emerges. This may be too large a question to resolve in one limited paper, but my examination of the boards' strengths and weaknesses suggests that, if land-claim boards are measured against the previous land and wildlife governance systems ("the alternative") rather than ideal but likely unattainable regimes ("the Almighty"), they may be judged successful.

Before the emergence of co-management regimes, the state management system, which afforded aboriginal people such minimal influence, was by no means the sole mechanism for regulation of wildlife harvesting and related activities across the Canadian North. Feit demonstrates that in that period, northern aboriginal people engaged in significant "self-management" of wildlife resources entirely outside the state system, sometimes as "local resistance to state forms of management" (Feit, 1988:74), and further, that self-management continues in the co-management era. Accordingly, the question is not whether aboriginal influence is greater in the land-claim boards reviewed in this paper than it was in the selfmanagement processes that have co-existed with state management for many years. By definition, it could not be. Rather, the question is whether, within the state system, that influence has increased with the advent of land-claim boards. For while the boards are unquestionably part of the state system, and indeed may be thought of as state constructs, a central rationale for their creation was the enhancement of aboriginal influence over key wildlife and environmental decisions.

Elements of self-management will doubtless persist, though it is well to ask whether the advance of co-management will complement or undermine self-management. A wholesale return to the original aboriginal methods of stewarding the land and animals used before the imposition of state management is simply not possible. An important reason underlying this assumption is that the boards under consideration here regulate not only wildlife use, but also major development projects such as pipelines, mines, and roads, which have no analogues in pre-contact aboriginal experience. Other alternatives to the boards could be imagined, but clear ideas as to what such regimes might entail, or how they might come to be, have yet to emerge.

Following a brief overview of the nature and range of land-claim boards, I consider the extent of aboriginal influence in these boards; the powers exercised by the boards and the decision-making clout they exercise; the question of their independence from other governments, both public and aboriginal; and their incorporation of traditional knowledge (TK) into their operations and decisions.

\section{NORTHERN LAND-CLAIM BOARDS: AN OVERVIEW}

An essential starting place is the recognition that the roughly two dozen boards established across the territorial North over the past two decades under the comprehensive land claims differ fundamentally from most of the myriad boards and political institutions permeating northern governance. As "modern-day treaties," comprehensive claims are constitutionally protected under section 35 of the Constitution Act, 1982. Accordingly, the boards, as integral components of the claims, enjoy quasi-constitutional status. This status accords them importance and permanence far beyond that of run-of-the-mill boards.

Land-claim boards, in a phrase explicitly used mainly in Nunavut, but applicable across the territories, are "institutions of public government." They do not constitute a form of aboriginal self-government, but neither are they part of the federal or territorial governments. They represent a new and unique set of institutions existing at the intersection of the three orders of government (aboriginal, territorial, and federal). Although specifics of claim negotiations varied across time and regions, generally speaking the boards emerged as a compromise between two quite different visions of governance. Aboriginal negotiators wished to incorporate as much control as possible over land and wildlife decisions into self-government regimes. The federal position, however, was that the public interest in such matters required control by public institutions. The boards thus emerged as a means of retaining public government in land and wildlife issues while distancing actual decisions 
and operations from federal and territorial government control and ensuring direct and meaningful participation by aboriginal peoples (Fenge, 1992). This compromise is evident, for example, in Article 5.1.2 of the Nunavut Land Claims Agreement, which states that "there is a need for an effective role for Inuit in all aspects of wildlife management, including research," while the following sentence stipulates that "government retains the ultimate responsibility for wildlife management."

The formal mechanisms by which boards are created vary. Some, like the Nunavut Wildlife Management Board, have their existence and mandate explicitly set out in the text of the claim itself. Others, for example the land and water boards in the Mackenzie Valley, came into being with the passage of federal legislation. (This latter situation might imply that the federal government could also legislate an end to such boards. Indeed, Parliament could pass legislation to abolish, say, the Mackenzie Valley Land and Water Board, but it would then be required under the Gwich'in, Sahtu, and Tlicho claims to establish an equivalent board with the same mandate and powers.)

The boards' jurisdiction is largely limited to wildlife, land, and environmental issues. Very few boards have mandates that extend more than marginally into conventionally defined social and cultural policy areas such as education, health, and social welfare. One exception is the Mackenzie Valley Environmental Impact Review Board (MVEIRB), whose legislation stipulates that "impact on the environment" is to include "any effect on the social and cultural environment," with the result that in conducting environmental assessments it "has the authority to consider socioeconomic impacts and impacts on the cultural well-being of the residents and communities in the Mackenzie Valley" (Donihee, 2001:33).

Land-claim boards fall into four broad categories. Boards in the first group deal with wildlife management. Their activities include setting general policy, as well as specific harvest levels for various species; directing wildlife research; and supporting local hunters and trappers' organizations. The Yukon Fish and Wildlife Management Board is an example. A second major set of boards is responsible for land-use planning: such bodies as the Gwich'in Land Use Planning Board set the frameworks that govern economic development projects, location of transportation facilities, and the like. A third group, which is involved in licensing projects that might disturb or damage the environment, has two subsets. One subset, illustrated by the Mackenzie Valley Land and Water Board, issues licences and permits to projects ranging from small gravel pits to oil and gas pipelines. The other subset conducts environmental impact assessments on proposed projects, usually the larger ones, as part of the licensing process. An example is the MVEIRB. The work of these boards is closely related to, though nonetheless separate from, the boards that issue permits and licences. Boards in the final group, represented by the Nunavut Arbitration Board, serve as dispute resolution bodies for claim-related issues. Thus far, they have had little significance; some have yet to have any cases referred to them.

Most boards have between 7 and 10 members, though a few are somewhat larger or smaller. Except for the underused arbitration panels, the board members have the support of a permanent, full-time professional staff (in some cases numbering only four or five, in others, a dozen or more) working out of well-equipped offices. A number of boards make extensive use of modern communication technology, for example, by maintaining online registries that make available the full texts of submissions and technical reports pertaining to projects under review.

In most cases, board members are formally appointed by the federal government, after nomination by one of the three parties to the claim (the aboriginal organization, the territorial government, and the federal government). Typically, half the board members are nominees of the aboriginal organization, although on some boards each party nominates one-third of the members. A number of board members nominated by government are also government employees, although on some boards this practice is explicitly prohibited.

Key to understanding the nature and role of the landclaim boards is the fundamental principle that they and their members are to act independently of the governments and organizations that nominated or appointed them. The legal frameworks establishing some boards explicitly state that members are to act "in the public interest" and not take direction from the parties that nominated them. Like judges, members are expected to use their best judgement and to reach decisions on the basis of the evidence before them. As might be expected, however, the question of board independence is not as straightforward as this simple formulation would have it. This question is examined in more detail below.

Funding for land-claim boards (for large, active boards, several million dollars a year) comes almost entirely from the federal government (the territorial governments provide some funding, but this is mostly redirected federal money). Funding, of course, impinges on independence and is considered as part of the analysis below.

In a limited number of cases, boards possess the legal capacity to make final, binding decisions on permits, harvest quotas, and the like. In most cases, however, and certainly in all matters with far-reaching implications, the boards have only advisory powers. They make recommendations to government, which need not take heed of the boards' advice. Put this way, the boards appear to wield little real clout because governments seem completely free to ignore their recommendations. This appearance is deceiving, however. The reality is quite different, as discussed below.

Land-claim boards decide, advise, and recommend. They have no powers of enforcement and rely on federal and territorial officials (e.g., wildlife officers and environmental inspectors) to put their recommendations into operation and to police the licences and plans they issue. 


\section{METHODS}

A review of primary documents and secondary literature relating to land-claim boards in the territorial North, supplemented by personal interviews and observation of selected board meetings, provided the basis of this paper. The interviews, all of which I conducted in person, were unstructured and covered all aspects of northern landclaim boards. Several dozen people agreed to be interviewed: members, former members, and staff of various land-claim boards; officials of the federal and territorial governments; and elected and appointed officials of various aboriginal organizations. These interviews, conducted on a not-for-attribution basis between 2000 and 2007, took place in Cambridge Bay, Dawson City, Igloolik, Inuvik, Iqaluit, Ottawa-Hull, Yellowknife, and Whitehorse. A number of respondents were interviewed more than once; several were interviewed three or four times. In a number of instances, additional information was obtained through follow-up telephone calls and e-mails. Direct quotations and paraphrases from those involved in board processes that are not otherwise attributed were taken from the notes of these interviews.

In terms of observation, I attended meetings of the Inuvialuit Game Council and the Wildlife Management Advisory Committee (NWT) in Inuvik in December 2001 and in December 2006, as well as those of the Nunavut Wildlife Management Board in Igloolik (September 2005) and Cambridge Bay (December 2007). I attended public hearings held by the Yukon Water Board in Whitehorse (February 2003 and June 2006) and the MVEIRB (Hay River, February 2004). I also attended a TK Workshop that the MVEIRB organized in Yellowknife in November 2002. The direct quotations of participants' comments from this workshop are taken from my meeting notes.

The data in Table 1 summarizing the cultural backgrounds of board members were drawn from biographical information available on board web sites; documents published by boards, governments, and aboriginal organizations; and personal knowledge of board staff and other persons familiar with the political and bureaucratic elites of the three territories.

\section{POWERS OF THE LAND-CLAIM BOARDS}

For aboriginal people to wield significant influence over decisions affecting their traditional lands and the wildlife on them through participation in land-claim boards, the boards themselves must possess real power. At first glance, though, the boards established under the comprehensive claims would seem to exercise little power, serving only in an advisory capacity to the federal and territorial governments, where the real power resides. However, as is so often the case in politics, formal relationships tell only part of the tale; in terms of effective decision making, land-claim boards can and do enjoy considerable power.
Even in purely formal terms, land-claim boards have certain limited authority to render decisions beyond the scope of federal or territorial ministers' power to override. By way of illustration, although the federal INAC minister may reject Class A licences issued by the Nunavut Water Board (on large projects, such as diamond mines), he or she must issue written reasons for the rejection. More significantly, the minister has scope only to approve or reject a licence and may not alter any of its terms and conditions. Moreover, most of the licences the board issues are Class B licences (on relatively small projects), which lie beyond the authority of the minister to alter or reject. Similarly, some of the wildlife management boards control millions of dollars in trust funds earmarked for research and allocate those funds to individuals and institutions for wildlife research, all without ministerial involvement or approval. Land-claim boards or their emanations also enjoy limited legal authority to create binding legal instruments; under the Inuvialuit Final Agreement (IFA), for example, local hunters and trappers' committees can pass what amount to legally enforceable regulations under the Northwest Territories Wildlife Act (Binder and Hanbidge, 1993). Other examples could be cited.

On major issues, however, land-claim boards lack final decision-making authority and are restricted to providing advice and recommendations to federal and territorial governments. But this advisory function is a far more potent prerogative than might be thought, in large measure because most board recommendations are framed in what might be termed a "negative option." In most governance regimes, advisory bodies typically submit proposals to government and hope that government will not only agree with the substance of the recommendations but also accord them sufficiently high priority to act on them. When landclaim boards make recommendations, in contrast, the responsible ministers usually have only a limited time, sometimes as short as 30 days, more often 60 or 90 days, in which to reject or (in some circumstances) vary the recommendations. Otherwise, the recommendations take effect. Accordingly, for land-claim boards the usual political calculus, whereby advisory bodies must expend political capital in an effort to convince ministers to accept recommendations, is reversed: ministers must expend their political resources (including laying out their objections in writing) and must do so quickly, or the land-claim boards' recommendations come into effect by default.

Ministerial rejection of such board recommendations is not unknown, but it is unusual. Few land-claim boards have had more than one or two recommendations overturned. Undoubtedly, many board recommendations have been allowed to pass into policy because government officials have recognized the high quality of the boards' research, consultation, and deliberations and accord their "advice" the respect it deserves. Also, boards have made recommendations that governments would have preferred not to deal with but could not ignore by virtue of the 
TABLE 1. Cultural backgrounds of land-claim board members (as of 1 January 2008). M = male, $F=$ female, UFA = Umbrella Final Agreement, and IFA = Inuvialuit Final Agreement.

\begin{tabular}{|c|c|c|c|c|c|c|}
\hline \multirow[b]{2}{*}{ Land-claim Board } & \multicolumn{2}{|c|}{ Aboriginal } & \multicolumn{2}{|c|}{ Non-Aboriginal } & \multirow[b]{2}{*}{ Total } & \multirow[b]{2}{*}{ Percentage Aboriginal } \\
\hline & $\mathrm{M}$ & $\mathrm{F}$ & $\mathrm{M}$ & $\mathrm{F}$ & & \\
\hline Yukon Fish and Wildlife Management Board & 12 & 1 & 12 & 5 & 30 & 43 \\
\hline Yukon Water Board (post UFA) & 13 & 3 & 13 & 5 & $34^{1}$ & 42 \\
\hline Nunavut Impact Review Board & 13 & 6 & 3 & 0 & 22 & 86 \\
\hline Nunavut Wildlife Management Board & 25 & 1 & 4 & 1 & 31 & 84 \\
\hline Mackenzie Valley Environmental Impact Review Board & 6 & 4 & 8 & 1 & 19 & 53 \\
\hline Mackenzie Valley Land and Water Board & 15 & 5 & 7 & 3 & 30 & 67 \\
\hline Environmental Impact Review Board-IFA & 9 & 1 & 13 & 1 & 24 & 42 \\
\hline Wildlife Management Advisory Committee (NWT)-IFA & 16 & 1 & 20 & 0 & 37 & 46 \\
\hline
\end{tabular}

${ }^{1}$ Excludes one female and three male members whose cultural background could not be determined.

"negative option" provision and the boards' political legitimacy. A good example is the Nunavut Wildlife Management Board's 1996 recommendation that Nunavut Inuit be permitted to harvest a bowhead whale, which the federal minister approved despite considerable domestic and international pressure (Hogh, 2000).

Two public servants (one federal, one territorial), reviewing their experience with ministerial responses to land-claim boards' recommendations, commented that "in practice [ministerial] rejection or modification of a decision carries with it a high political risk and is rare" (Bannon and Dunlop, 1998:4). A similar conclusion was reached from the aboriginal point of view: Simmons and Netro (1995:171) noted that although the Yukon Regional Resource Councils, which are closely linked to the Yukon Fish and Wildlife Management Board, only offer "advice" to government, it is "advice with a difference...this is a considerable restriction on the traditional powers of a Minister of the Crown." It may even be that, as Usher (1993:113) noted for the Beverly-Qamanirjuaq Caribou Management Board, "ministers and senior managers seem to have recognized the political advantages of letting the Board take responsibility for some difficult decisions rather than imposing their own solutions."

\section{ABORIGINAL PARTICIPATION AND INFLUENCE IN LAND-CLAIM BOARDS}

A necessary but not sufficient condition for genuine aboriginal influence on land-claim boards is a substantial aboriginal presence on the boards. If only token numbers of aboriginal people serve as board members, it would be difficult to argue that aboriginal interests and worldviews are taken seriously into account in board deliberations. A quick look at the data, however, demonstrates that indeed aboriginal peoples are well represented in the membership of land-claim boards. Aboriginal organizations almost always put forward aboriginal persons as their nominees, and territorial governments frequently nominate aboriginal persons, as does (on occasion) the federal government. Accordingly, on many boards, aboriginal members constitute a clear majority. Table 1 presents data, as of 1 January 2008, on the membership of eight boards across the three territories, two from Nunavut, two from the Yukon, and four from the Northwest Territories, two from the Mackenzie Valley and two from the Inuvialuit region (where the boards established under the 1984 Inuvialuit Final Agreement differ fundamentally from those subsequently established in the Mackenzie Valley). These boards are not presented as a strictly representative sample of all land-claim boards, but the pattern of their membership composition almost certainly holds across the entire range of boards.

Table 1 indicates the number of aboriginal and nonaboriginal persons appointed to the boards since they were created (or, in the case of the Yukon Water Board, recast as a land-claim board under the 1993 Yukon Umbrella Final Agreement), and within those categories, the numbers of male and female members. The picture which emerges is an approximate one, in the sense that it does not take into account the highly variable tenure of board members: some serve for only a year or two, while others stay on for a decade or more. As well, a person who served two or more noncontinuous terms on a board was counted only once.

Dichotomizing land-claim board members on the basis of their aboriginality is not meant to imply that nonaboriginal members routinely adopt opposing positions to those of aboriginal board members; to the contrary, board proceedings and decisions are more typically marked by consensus among all members. Nor is it meant to imply either that all aboriginal members always agree on issues coming before the boards, any more than all non-aboriginal members are always in agreement. When disagreement does arise, members' positions reflect a range of factors that could include personal views, cultural background, regional perspectives, and institutional affiliation.

Though on several dimensions, there are limitations on the inferences to be drawn from the raw numbers of landclaim board members who are aboriginal, the data in Table 1 are instructive. The proportion of aboriginal board members on the eight boards ranges from over $40 \%$ to nearly $90 \%$, and not surprisingly, the highest proportions are registered in Nunavut, where Inuit constitute close to $85 \%$ of the population. An analysis of Nunavut "Institutions of Public 
Government" or IPGs (the common term in Nunavut for land-claim boards) conducted as part of the first five-year review of the Nunavut claim found that some $86 \%$ of landclaim board members were Inuit (Vertes et al., 1999). The figures for the Wildlife Management Advisory Council (NWT) underestimate Inuvialuit participation, in that they include a substantial number of alternate members (to fill in should regular members be unavailable). Although the Inuvialuit Game Council also appoints alternates, they are not as numerous as the government-appointed alternates, who are overwhelmingly non-aboriginal.

A small but significant fact emerging from Table 1 is that nearly half the members of the Yukon Water Board have been citizens of Yukon First Nations. These data include only appointments made after the finalization of the Umbrella Final Agreement (the essential framework for the Council of Yukon Indians claim). This board existed, in different form, prior to the claim, but in the nine years (1987-96) before implementation of the claim began, only one of 12 Yukon Water Board members (8\%) was from a First Nation. Clearly, the transition to landclaim board status has been accompanied by a vast increase in First Nations participation in the board's work.

Given that board members' tenure varies substantially, the figures in Table 1 could be recalculated on the basis of years of service by aboriginal board members, but it is unlikely that a substantially different picture would emerge. Either indicator - the simple proportion of aboriginal board members or the proportion of aboriginal board serviceyears-is at best a rough proxy for actual aboriginal influence. The data in the table serve adequately to demonstrate that there are enough aboriginal members on landclaim boards to make a difference.

Table 1 demonstrates clearly that, while aboriginal people are well represented among the members of land-claim boards, women are dramatically underrepresented, as is the case in so many other facets of northern governance. Roughly one board member in six is a woman (the proportions are similar for both aboriginal and non-aboriginal women). These findings are similar to those emerging from a study by Pauktuutit, the national Inuit women's organization, which found that only $9 \%$ of the elected positions on local hunters and trappers' organizations (HTOs) in Nunavut were held by women (CBC News, 2006).

The raw numbers, of course, indicate aboriginal participation in land-claim boards, but what of influence? An authoritative, systematic assessment of aboriginal influence, if indeed such an exercise would even be possible, is beyond the scope of this paper, but a range of indicators suggests that indeed aboriginal influence on land-claim boards is substantial.

A telling incident occurred at a TK workshop in Yellowknife in 2002. A young Dene man angrily attacked the MVEIRB as unrepresentative of the local aboriginal people, proclaiming: "Your [MVEIRB] views don't fit with ours ... the real decision-making power should go to the communities ... the MVEIRB doesn't really work." At this, an aboriginal MVEIRB member, a respected elder with long years of Dene politics behind him, responded with equal force, defending the claim regime of which the board is a key element: "Twenty-five years ago we were nothing ... now I can make a decision and tell the government what to do ... I sit on the board to do the work our elders said we should do 25 years ago."

In interviews, aboriginal board members, as well as officials of aboriginal organizations, generally took the position that land-claim boards do offer aboriginal people significant influence over land and resource matters, although some expressed a desire for a good deal more. A veteran Inuit leader, for example, acknowledging that the Nunavut landclaim boards are for many Inuit discouragingly formal and bureaucratic, accepts this as "a necessary evil" in light of their notable successes "in bringing issues down to the people in the communities and speaking their language." Similarly, an official of Nunavut Tunngavik Incorporated (NTI), the Inuit land-claim organization, observed that "bridging the two worlds of Inuit ways and Western ways is the real challenge. Bringing the Inuit way into land and wildlife decisions is the strongest argument in favour of the IPGs in the first place...the IPGs create the opportunity for the little guy in the community to have an impact."

Other interviewees noted with approval the fact that the boards charged with environmental regulation are required by law to ensure that communities within the claim areas, many of which are overwhelmingly aboriginal, are informed and consulted about proposed projects and their potential impact. Not only must communities be accorded the opportunity to bring forward their views on such proposals to the boards reviewing them, but the proponents must respond in public to community concerns. These requirements do not, of course, bestow upon the communities the authority to reject proposals, but they enhance aboriginal influence over the process, and indeed, its outcome.

The closest approximation of a survey assessing aboriginal influence on land-claim boards is found in the initial five-year review of the Nunavut claim. The researchers conducting the review asked both business leaders and representatives of local, Inuit-dominated HTOs about Inuit influence on public policy. Nine of ten businesspeople were of the view that Inuit have effective control over some or most important decisions affecting land and water, while all 14 HTO officials who responded said that they had more rather than less control over wildlife decisions since the claim came into effect (Vertes et al., 1999). Neither group was asked directly about the land-claim boards involved in these areas, but given the boards' status as central players in land, water, and wildlife decisions, it is reasonable to assume that respondents' answers can be taken as positive assessments of Inuit influence through the boards.

The secondary literature tends to the view that aboriginal people enjoy meaningful influence over land and wildlife decisions through their participation on landclaim boards and that this influence far exceeds what had 
been possible prior to the claims. In reviewing this literature, it is important to recognize that not all assessments of aboriginal influence in co-management regimes, some of which reach negative conclusions, look at land-claim boards. Nadasdy (2003), for example, found little First Nation influence in the workings of the Ruby Range Sheep Steering Committee, a non-claim-based co-management board in the southwest Yukon. Although some assessments of aboriginal influence in another non-claim comanagement institution, the Beverly-Qamanirjuaq Caribou Management Board, are positive (Usher, 1993; Treseder and Honda-McNeil, 1999), others are far less sanguine (Kendrick, 2000; Spak, 2005).

In a comprehensive analysis of the first decade of the Inuvialuit Final Agreement, long-time observer and participant Lindsay Staples concludes unequivocally that, since the signing of the claim, Inuvialuit involvement in wildlife management has "improved dramatically" (Staples, 1995:3). In his words, "The participation of the Inuvialuit in the IFA management regime is both extensive and substantive, and has had a significant influence on government decision making" (Staples, 1995:49). Binder and Hanbidge (1993) are similarly sanguine about the IFA; in an early analysis, Doubleday (1989), while adopting a wait-and-see stance before rendering judgement, was optimistic about the prospects for Inuvialuit influence through the IFA and its boards. A decade later, Treseder and Honda-McNeil (1999) weighed the successes and failures of wildlife co-management boards and found that the former outweighed the latter. Usher (2003:379), who has decades of experience as both member of and advisor to land-claim boards plus a wide-ranging academic perspective, wrote: "The comanagement arrangements [of landclaim boards] work well in principle and in practice for both humans and the environment." Galbraith et al. (2007:36) rate the environmental assessment process of the Mackenzie Valley Environmental Impact Review Board as "exemplary," in part because it goes significantly farther in meaningfully involving aboriginal people in environmental regulation than most such processes in Canada and elsewhere. At the same time, they also recognize shortcomings in this regard, for example, aboriginal people's mistrust of the process, a lack of capacity to participate effectively, and insufficient resources devoted to TK.

However, not everyone shares these generally positive assessments. As discussed below, some harsh critics of the wildlife management land-claim boards dispute the proposition that through them aboriginal influence over their land and resources has improved substantially, if indeed at all, since the days of the DIAND-controlled regime.

\section{BOARD INDEPENDENCE}

Central to any evaluation of aboriginal influence on land-claim boards is the question of board independence from government. To the extent that boards are controlled, directly or indirectly, by government, aboriginal influence will necessarily be, at best, limited. Three elements impinge on board independence: the appointment process, the orientation and behaviour of board members, and funding levels and processes.

\section{Appointments}

Most appointments of board members, even those nominated by aboriginal organizations and governments, are formally made by the federal government. On a few boards, such as the Wek'eezhii Land and Water Board and the Wildlife Management Advisory Council (North Slope), formal appointment power is lodged with the aboriginal organization or government. As devolution of jurisdictional authority over fields currently held by Ottawa proceeds, the territorial governments are likely to become the appointing agency. This change has already occurred in the Yukon. Since 2005, with the devolution of authority over most natural resources, members of the Yukon Water Board have been appointed by the Yukon government.

Prospective board members are subject to a criminal background check, but other than nominees who fail to clear that hurdle, those proposed for board membership by aboriginal governments or organizations are routinely accepted and duly appointed by the federal (or territorial) government. Neither the public record nor the interviews revealed any significant concerns about government willingness to appoint persons nominated by aboriginal organizations and governments. Discontent was repeatedly registered over the length of time it took for Ottawa to move forward with proposed appointments. Delays were not interpreted as attempts at interference or control, but as an indication of Ottawa's normally sluggish procedures and, more significantly, as a measure of the low priority it accords northern land-claim boards. Some boards have publicly complained about the lack of federal attention to filling vacant board positions, leaving them for months with insufficient numbers to reach quorum and thus unable to meet and transact business (CBC News, 2005).

One recent and highly controversial appointment raised concerns about Ottawa's use of its appointment prerogative to influence an important board. When a replacement was needed for the chair of the Mackenzie Valley Land and Water Board, it was generally expected that, as in the past, Ottawa would appoint one of the three persons shortlisted by the board itself. The federal minister, however, rejected the board's recommendations and appointed instead an individual who had been the focus of intense conflict and accusations of bias when he had previously chaired the Mackenzie Valley Environmental Impact Review Board. Particularly because, unlike other board members, he was an INAC employee, concerns were expressed that he had been parachuted onto the board to do Ottawa's bidding on issues relating to the proposed Mackenzie Valley pipeline. His appointment generated debilitating discord within the board, including a call by board members for his resignation. 
The situation, which hamstrung the board for months, was resolved only when the chair resigned (Bryant, 2005; Danylchuk, 2005; Hunsley, 2005).

The same individual was also at the centre of the most noteworthy contretemps involving the obverse of the government's appointment power: the ability to remove board members. In general, interviews revealed all but negligible concern that Ottawa was abusing its legal (but seldom invoked) authority to dismiss board members. The outstanding exception was the ouster of a prominent and outspoken member of the MVEIRB, whose appointment was revoked following his attacks on the chair for promoting the agenda of the federal government. Although this episode dramatically raised apprehensions about Ottawa's commitment to board independence, it is important to recognize that the deposed board member had been a federal nominee. Had he been a nominee of an aboriginal government or organization, the political implications would have been more far-reaching.

Nor have territorial governments been immune from criticism that they have used their appointment (or nomination) power to sway board decisions. For example, one of the toughest, most divisive issues faced in recent years by the Yukon Fish and Wildlife Management Board involved game farms. When his term expired, a board member who was vocally opposed to game farming was replaced by a person who runs a game farm. "You don't get much more blatantly obvious than that," as one observer commented, when it comes to political interference.

\section{Board Members' Orientation and Behaviour}

Except for the Inuvialuit boards (members of which are explicitly recognized as representing, in the sense of promoting the interests of, the parties that nominated them), a central principle is that, once appointed, board members are to exercise their best judgement on the issues before them and not take instruction or direction from nominating parties. At the same time, as is the case with appointments to quasi-judicial agencies throughout Canada, it is widely presumed and accepted that the nominating parties are confident that their nominees hold compatible views.

Although boards collectively, and members individually, take seriously the duty to be independent, it is not unusual for board members to feel obligated to take positions that are in line with the preferences of the party that nominated them. Yet this is quite different from parties directing "their" members and, in that members' views will often be similar to those of their nominating parties, does not per se constitute a significant threat to board independence.

A special case of board members acting in ways that their nominating parties would want occurs when government employees serve on boards that deal with issues directly affecting their departments. As noted above, civil servants are explicitly excluded from membership on some boards, but on others it is hard to imagine that their status as government employees does not affect how they respond to certain issues. Although the interviews confirmed that civil servants' behaviour as board members is sometimes determined by adherence to government policy, the interviewees also disclosed important instances of civil servants who at board meetings had adopted positions running directly contrary to government policy. One board executive director contrasted the behaviour of two bureaucrat board members: "One is almost reporting minute by minute to his director general; another seems to have very little communication with his department." A review of the IFA environment and wildlife provisions illustrated how significant this issue may be: "In one case, a government employee was subjected to career-threatening pressures because of a decision of the joint body of which he was a member was at odds with the views of his senior managers" (Resource Futures International, 1993:32).

That aboriginal organizations may view board members they have nominated as "their" members was evident in interviews. It may also be seen in the ads they run soliciting applications for board positions (all three parties routinely publish ads and brochures seeking potential candidates). By way of illustration, NTI recently put out a call for candidates for the Nunavut Impact Review Board and the Nunavut Water Board, which included this statement: "Candidates must be actively and personally committed to representing the interests of Beneficiaries of the Nunavut Land Claims Agreement" (NTI, 2005). The ad did not indicate that only Inuit ("beneficiaries") would be considered, nor did it imply that members would be expected to take direction from NTI. Nonetheless, the clear signal that in NTI's view the member should represent Inuit interests, as opposed to the interests of all Nunavut residents, is significant.

Two recent episodes involving boards that had become dysfunctional suggest that, for some key northern aboriginal political figures, land-claim boards are ultimately seen as emanations of the federal state. In 2005, longstanding tensions within the Nunavut Planning Commission erupted with demands by board members for the resignation of the chair (a veteran Inuit politician) on the grounds of financial irregularities and his refusal to call board meetings; board members also attempted to hold meetings without the chair. The chair reacted by writing to the federal minister, seeking "direction" in resolving the situation, and leaving it up to the minister as to whether the Nunavut Government and NTI should be consulted (Bell, 2005). Simultaneously, Northwest Territories Premier Joe Handley responded to the Mackenzie Valley Land and Water Board imbroglio mentioned earlier by demanding that the federal minister do whatever was needed to get the board back on track (Danylchuk, 2005).

The orientation and behaviour of board staff is not usually relevant to the issue of board independence, but does impinge directly on it in at least one instance. Staff of the Yukon Salmon Committee (technically a subcommittee of the Yukon Fish and Wildlife Management Board although relations between the two bodies are cordial but 
distant), including its top official, the executive secretary, are employees of the federal Department of Fisheries and Oceans, typically working part-time for the Salmon Committee. This situation contributes to a public perception that the committee is an arm of the DFO. One interviewee found it significant that committee staff speak in terms of "us" (meaning DFO) and "them" (meaning the Salmon Committee). On occasion, this staffing arrangement has a real effect on the committee's independence. As one staff person put it, "On some issues, the advice to the committee would be different if we didn't work for the department." Conversely, though, one knowledgeable observer of the Yukon Water Board argues that the fact that board employees are formally employees of the territorial government enhances their capacity to resist occasional government pressure because of the security they enjoy (as opposed to being employees of a small, stand-alone agency).

\section{Funding}

None of the land-claim boards has the authority or capacity to generate any meaningful revenue, so they are all but entirely dependent on government (normally the federal government) for funding. This situation raises a key question of board independence: does what has been termed the golden rule of politics, "He who has the gold rules," apply to boards?

Two dimensions of funding are germane to answering this question: funding levels and funding mechanisms. Both in interviews and in public documents, members and staff of land-claim boards express a mixture of satisfaction and displeasure with overall funding levels. As with virtually any governmental organization, there is never enough money to do everything worthwhile that boards would like to do, but sufficient money is usually forthcoming to take care of most core board responsibilities.

Detailed though they may be, comprehensive claims are fleshed out by even more detailed implementation contracts (agreed to by the three parties), which set out, among other things, basic funding levels for boards. The figures in these contracts are usually supplemented with funds earmarked for special projects or needs. For regulatory boards, which cannot predict with any certainty the number and length of hearings they will be required to conduct in a given year, it is understood that government will accede to the costs incurred in such hearings, and by and large, boards have been satisfied with the funding they have received for hearings.

The Nunavut land-claim boards that made submissions to Justice Thomas Berger, in his role as conciliator in the deadlocked negotiations over a second implementation contract, did express frustration that they were unable to pursue what they saw as essential activities for lack of funds (Berger, 2005). In the Northwest Territories, the counsel for the MVEIRB has written that "the federal government has not provided the resources or the support needed by the Mackenzie Valley Boards" (Donihee, 2001:47). Overall, despite a certain level of complaining about the constant need for more money, land-claim boards are funded reasonably well enough to discharge their responsibilities. To the extent that they complain about funding levels, they do not perceive this deficiency as a significant threat to their independence.

More problematic are issues relating to the mechanisms of funding. As noted, basic board needs are set out in the implementation contracts (although the prolonged stalemate in negotiating a new contract for the Nunavut claim raises important questions about their status). However, to gain access to these funds, boards are required to submit detailed budgetary projections and financial audits to Ottawa and generally acquiesce to the federal government's financial management processes. Aside from the administrative burden these requirements impose on the boards, they come with the ever-present possibility that requests will be turned down or reduced, a clear threat to board independence. Tied in with such concerns is the reality that the federal bureaucrats who deal with board funding tend to be specialists in process rather than policy substance. As one board official put it, "These officials are not associated in any direct way with resource management and seem only loosely connected to the day to day exigencies of board operations. This in my view is a strained way to administer funding for public government resource management institutions and it causes problems" (Donihee, 2001:40).

A small but symbolically important illustration is Ottawa's control over the setting of the per diem payments to board members. Boards across the North have complained that their members' per diems are inappropriately low, to the point where they create a significant disincentive for serving on boards. For example, although rates have been increased since then, in 2001, MVEIRB members were paid an honorarium of $\$ 200$ a day, while a panel member of the federal Canadian Environmental Assessment Agency received $\$ 575$ a day.

From the board perspective, improvements have been made, such as Ottawa's shift in 2000 from funding boards through "contribution agreements" (which, among other things, required repayment of unspent balances at year end) to a less constraining "flexible transfer payment" process (White, 2002). Yet major funding issues remain that impinge directly on board independence, as evidenced by Ottawa's continuing refusal to use the arbitration processes set out in the Nunavut claim to resolve disagreements about board funding levels. In the words of Justice Berger (2005:16), "The Inuit can be forgiven for seeing the refusal to arbitrate the issue of adequate funding as a mechanism for simply imposing Canada's determination as to appropriate funding levels."

\section{TK IN LAND-CLAIM BOARDS}

One of the great potential strengths of land-claim boards, at least from an aboriginal point of view, is their commitment to incorporating traditional knowledge into not only 
their decisions and recommendations, but also their operations. It would be hard to build a case for meaningful aboriginal influence via land-claim boards if the boards paid little attention to such a central component of aboriginal existence as traditional knowledge. A full account of the nature of TK is far beyond the scope of this paper. The concept of TK informing this paper is Berkes' (1999:8) well-known formulation: "a cumulative body of knowledge, practice and belief, evolving by adaptive processes and handed down through generations by cultural transmission, about the relationship of living beings (including humans) with one another and with their environment."

Assessing northern land-claim boards' use of TK is to some extent a question of whether the snowmobile's gas tank is half-full or half-empty. Across the territorial North, land-claim boards now routinely base decisions on the traditional knowledge of local aboriginal people. This marks a very significant departure from earlier statecontrolled land and wildlife regimes in which TK was largely or entirely ignored by government decision makers. Wildlife management boards certainly rely heavily on scientific data obtained through aerial surveys, DNA testing, satellite monitoring of radio-collars and the like. Yet they also listen carefully to the experiences and perceptions of local hunters and elders with extensive first-hand knowledge of the land. As well, wildlife boards make concerted efforts at incorporating TK and harvest information provided by local hunters into the gathering and assessment of baseline data on the size, health, and migration patterns of various species populations. Some important studies, such as the Nunavut Wildlife Management Board's landmark Nunavut Harvest Study and its Inuit Bowhead Knowledge Study have relied primarily on locally gathered TK.

TK also plays a significant role in the work of the environmental regulatory boards established under the claims. The legislation establishing the Mackenzie Valley Environmental Review Board, for example, explicitly requires the board to take TK into consideration in its work, and the board's policy documents reiterate its commitment to TK (Christensen and Grant, 2007). Nor is this commitment mere lip service, as two recent board decisions illustrate. In 2004, the board recommended to the federal minister that a proposal for a very small diamond exploration project at Drybones Bay on Great Slave Lake be rejected, principally on the grounds that for nearby aboriginal people the area is "a vitally important cultural and heritage area" that stood to be significantly and adversely affected by exploration and development activity (MVEIRB, 2004:61). This recommendation was heavily influenced by the TK presented to it during the environmental assessment process and by the proponent's failure to satisfactorily acquire and consider TK (MVEIRB, 2004). Early in 2007, the board recommended that a small, exploratory uranium-drilling operation proposed for the Upper Thelon basin not proceed because it would lead to "adverse cultural impacts of a cumulative nature to areas of very high spiritual importance to aboriginal peoples," noting that in reaching this conclusion "the Review Board paid particular attention to the Elders' traditional knowledge about the Upper Thelon" (MVEIRB, 2007:4). Despite heavy lobbying from an outraged mining industry, the INAC minister signed off on both recommendations, effectively stopping both projects in their tracks. Not all proposed projects opposed or questioned on the basis of TK have been halted, but many have been significantly modified in response to board directives drawing at least in part on TK. As well, developers have adapted to the new regulatory regime by incorporating TK into the design of their proposals.

In short, TK is taken seriously by land-claim boards and significantly influences their decisions and recommendations. This is noteworthy, given the conclusion of a recent overview of the field, emphasizing practices in North America, that "despite the growing awareness of the importance for natural resource management, the current regulations and practices in many regimes still do not provide effective formal mechanisms of TEK into active management" (Menzies and Butler, 2006:2).

If boards have become reasonably adept at soliciting and using specific factual (often highly localized) elements of TK, such as community knowledge of animal behaviour (e.g., caribou migration patterns, effects of increase or decline of certain predators, etc.), they have been less successful at bringing other fundamental aspects of TK to bear on their work. The distinction drawn here is between relying on $\mathrm{TK}$ in the assessment of particular projects and bringing TK to bear on board processes and operations. In a study of TK in land-claim boards, most notably the MVEIRB and the Nunavut Wildlife Management Board, I have argued that despite substantial and sincere efforts on the boards' part to incorporate TK into their practices, their capacity to do so is limited by the exigencies of the modern bureaucratic state, the central tenets of which are in fundamental ways incompatible with TK (White, 2006). TK encompasses far more than just what might be termed "local environmental knowledge." TK entails analyses and prescriptions for all manner of social interactions among people and between people and animals, as well as deeply spiritual and philosophical precepts. At a very basic level, practices such as aggressive cross-examination of elders by corporate lawyers and requirements for information brought before boards to be made public can be directly contrary to TK principles. More fundamentally, the cosmological elements of TK simply represent a worldview very much at variance with the worldview underpinning EuroCanadian governance models, in which land-claim boards are firmly rooted.

Thus, if the measure is the extent to which land-claim boards base decisions and recommendations on TK, significant aboriginal influence is clearly present. However, if the criteria include how well boards incorporate TK into their operations and processes, the limits on aboriginal influence are equally clear. 


\section{CRITIQUES OF LAND-CLAIM BOARDS}

Analysis of the role played, or not played, by TK in land-claim boards offers a good entry point to the most serious critiques of land-claim boards. For anthropologists Paul Nadasdy and Marc Stevenson, the all-but-complete absence of TK, in its cosmological sense, from co-management processes bespeaks fundamental problems with the entire regime. Although their arguments apply to the entire range of land-claim boards and they refer in passing to environmental licensing and review boards, their analyses are rooted in the experiences of wildlife co-management boards. Much of their evidence comes from boards that did not arise from land claims, but their critiques are sufficiently broad as to bear directly on land-claim boards.

In his study of the Ruby Range Sheep Steering Committee, Nadasdy (2003) anchors his analysis in the development literature and examines how language and discourse shape perceptions and behaviour. His central conclusion: "Without denying the sincerity of those who hope for improved management and the empowerment of First Nation people through co-management, we must also acknowledge that the complex process of co-management may have a number of other unforeseen - and unintendedconsequences.... Rather than empowering local aboriginal communities...co-management may actually be preventing the kind of change proponents desire. Indeed, comanagement may actually be serving to extend state power into the very communities that it is supposedly empowering" (Nadasdy, 2005:216).

Nadasdy (2005) rejects what has become a standard justification for co-management regimes: that comanagement is more effective than state management because it can incorporate TK into decisions. He maintains that to be of use in co-management processes, TK must be so simplified and taken out of context that it has little value or impact in actual decision making. However, this phase of the analysis is brief and insufficiently developed to be convincing. Far more compelling is his discussion of another principal justification for co-management: that it empowers local aboriginal people. His argument largely rests on the proposition that "by ensnaring participants in a tangle of bureaucracy and endless meetings" co-management inhibits rather than fosters "meaningful change" (Nadasdy, 2005:224). This undesired outcome occurs because, to participate effectively in co-management, aboriginal people have had to adopt Western bureaucratic structures, norms, and ways of thought: "to participate...they have had to accept the rules and assumptions of the state management game" (Nadasdy, 2005:225). The implicit but unarticulated conclusion is that by enmeshing themselves in processes and discourses so incompatible with aboriginal worldviews and approaches, they damage their culture and reduce their capacity for selfdetermination. Certainly he is clear that co-management regimes, rather than "giving aboriginal people increased control over their lives and land might instead be seen as subtle extensions of empire, replacing local aboriginal ways of talking, thinking and acting with those specifically sanctioned by the state" (Nadasdy, 2005:228).

Stevenson (2006:170) accepts this logic, but is harsher in his judgement, stating for example that the article of the Nunavut claim establishing the Nunavut Wildlife Management Board and its objectives and processes "introduces concepts so alien to traditional Inuit values and understandings... as to be a recipe for the destruction of Inuit culture." Nor is he as charitable as Nadasdy, who sees many players in the state co-management system as sincere and well intentioned, but unmindful of its subtle effects. Stevenson (2006) tends to see what he terms "the conservation bureaucracy" as willfully dismissive of aboriginal people's views and methods and unconcerned about co-management's deleterious effects not only for aboriginal culture, but also for preserving sensitive ecosystems.

Like Nadasdy, Stevenson (2006:168, 170) maintains that the conceptual framework of "environmental resource management" (ERM) and the discourse it promotes "has rendered traditional Aboriginal ways of relating to their lands and resources virtually invisible in co-management ... whatever terminology and understandings that Aboriginal participants bring to the table are quickly dismissed as being anecdotal, unscientific or incompatible with ERM and western law." His overall assessment: "Aboriginal peoples' participation in state-sponsored projects of comanagement has served to disempower them by creating virtually insurmountable barriers to the inclusion of their values, understandings, knowledge and institutions into these processes" (Stevenson, 2006:172).

In drawing our attention to the subtle yet powerful and far-reaching implications of the ideational context of comanagement, Nadasdy and Stevenson provide valuable insights into essential elements of land-claim boards. They are unquestionably correct that, as Stevenson (2006:169) puts it, "in order to advance their needs, rights and interests in co-management, aboriginal peoples have adopted the languages, approaches and institutions of ERM and British parliamentary law" and that, as Nadasdy (2005:225) argues, co-management, as practiced in northern Canada is not an "alternative to" but a "variation within" the bureaucratic state. However, are they correct in concluding that participation in co-management arrangements is on balance disadvantageous to aboriginal people? Do their analyses lead to alternative proposals with a reasonable likelihood of coming to fruition? In my view, the answer in both cases is no.

Both Nadasdy and Stevenson rely heavily on examples from co-management boards not based on claims. Their arguments about the dominance of the Western bureaucratic paradigm are clearly applicable to land-claim boards. However, their judgment that aboriginal insights and interests are not taken seriously in board decision making lacks sufficient empirical support to warrant accepting that it applies to the entire range of land-claim boards. In mandate, powers, and in other ways, land-claim boards 
differ in significant ways from boards not arising from land claims. Moreover, as noted above, developing measures for and then carrying out a thorough, systematic assessment of aboriginal influence on land-claim boards would be a major undertaking. In the absence of such a study, on the basis of a variety of formal interviews, informal discussions, and personal observation, I am sceptical of sweeping generalizations that dismiss the prospect of significant aboriginal influence on land-claim boards from limited evidence.

Many in northern aboriginal communities (as in government and in non-aboriginal circles) have criticisms, both minor and fundamental, of land-claim boards, but few would countenance a return to the days when aboriginal people played little if any role in wildlife and environmental decisions made by Ottawa and the territorial governments. Some evince disappointment that the claim regimes have not lived up to their promise; others believe that, from the outset, the compromise that the boards represent tilted too much to government. However, few people (and none of those interviewed for this project) dispute that aboriginal influence has increased through land-claim boards. That the compromise failed to satisfy those seeking something akin to aboriginal control of land and resources is clear, but as Usher (1996:58) observed, "the claims agreements are the results of negotiations, hence do not represent so much what the aboriginal parties sought as much as what they (or their advisors) thought they could get government to agree to in the particular historical context in which they were negotiated." Moreover, the compromises that aboriginal negotiators accepted did not just entail differing visions of wildlife management. Often wildlife management provisions were part of larger compromises involving other components of the claim (Doubleday, 1989; Fenge, 1992).

Perhaps so, Nadasdy and Stevenson might concede, but at what cost to aboriginal culture? This is an exceptionally difficult question to answer, even for observers as experienced and knowledgeable as Nadasdy and Stevenson. Without denying the hegemonic power of the Western bureaucratic paradigm, we should not underestimate the resilience of aboriginal cultures or their adaptability. Consider, for example, how modern communication technologies at once threaten aboriginal cultures and are used to foster them. Does learning the rules of the co-management game, developing bureaucratic expertise and engaging in the discourse of state management necessarily entail a loss of culture for aboriginal people? Aboriginal cultures are not static and have repeatedly demonstrated remarkable capacity to retain their central defining values in the face of changing circumstances. This observation is not to downplay the threats to aboriginal cultures from a host of developments, including loss of language and severing of links to the land, but rather to suggest that the health of aboriginal cultures is a complex matter.

As well, we must be careful about reading too much into the language of land-claim boards, symbolically important as language may be. By way of illustration, Stevenson (2006) and others (e.g., Spak, 2005) accord considerable weight to the observation that the very notion of "managing" wildlife is inconceivable and absurd in traditional northern aboriginal cultures. True enough, but as Natcher et al. (2005:241) noted, "co-management has more to do with managing human relationships than resources per se." An aboriginal member of a wildlife management board put it this way: "We want to manage people, not fish and wildlife."

Finally, what alternatives do the critics proffer from their pessimistic analyses of co-management? Nadasdy (2003:145) proposes "the devolution of control over local land and resources to aboriginal communities themselves and this would have to include not only control over wildlife but also over all forms of development." As he recognizes, this devolution would entail "a radical rethinking of the basic assumptions, values, and practices underlying contemporary processes of resource management and environmental impact assessment" (Nadasdy, $2003: 145)$, though precisely how this would come to be is vague. In response, Hunn et al. (2003:S80) observe:

His "solution" imagines a world in which colonial
occupation and settlement never occurred and nations
willingly concede their sovereign power. In reality,
indigenous communities must necessarily engage an
encompassing polity that holds ultimate power. It would
seem more in the interest of the survival of indigenous
communities to foster a dialogue, however imperfect,
with the professional scientists and resource managers
entrusted by national governments with the "protection
of our natural resources."

In a later publication, Nadasdy (2005:228) does not go beyond the admonition "that anthropologists and other scholars critically examine their own involvement in processes of knowledge-integration and co-management." This is sound advice, but hardly a blueprint for significant structural change.

Stevenson (2006) proposes an approach based on the "two-row wampum," a symbol of two canoes travelling parallel paths in peace and friendship, which would create space for aboriginal people and their modes of thought and knowledge systems in co-management processes. This proposal would be effected primarily through better education for non-aboriginal resource managers "to develop a new professional literacy that equips them with an understanding about how resource management decisions reflect and affect the social, cultural and political settings in which they live and work" (Stevenson, 2006:176).

Stevenson's proposal would not be an easy undertaking but would doubtless have salutary effects on the culture, operations, and decision making of land-claim boards. However, it would not fundamentally change the institutional framework within which the boards operate; boards would remain firmly established as part of the bureaucratic 
state system (with ministerial override provisions firmly in place). As Usher (2003:379) noted, co-management is "the antithesis of the parallel canoe approach." Stevenson's idea is worthwhile, but falls far short of radical restructuring of the land-claim board regimes, let alone their replacement with something that would return land and wildlife decisions to aboriginal peoples.

Nadasdy and Stevenson both focus their critiques on wildlife management boards and have little to say about other types of land-claim boards, most notably those engaged in environmental regulation. Wildlife management regimes controlled by aboriginal people, and run on the basis of thoroughgoing TK principles and aboriginal cultural mores, with minimal state influence, are certainly conceivable. Such principles and mores can be-and indeed are-incorporated to some extent into regulatory processes for assessing and mitigating the environmental impact of major infrastructure and economic development projects such as mines, pipelines, dams, and roads (as well as processes for approving or rejecting them). However, it is difficult to imagine such a regime outside the realm of state processes and conceptual frameworks. The state simply has too extensive an interest in major projects to forgo deep involvement in regulating them. And of course, the power imbalance between aboriginal communities and governments on the one hand and the state on the other heavily favours the state. Nor is there anything like an analogue in traditional aboriginal experience for regulating large-scale resource extraction projects, as there is for wildlife management. Otherwise put, it seems inevitable that environmental regulation will proceed along statesanctioned lines, with considerable scope for aboriginal influence, but not complete control. In turn, this suggests that the possibility of the state's "devolving control over local land and resources to Aboriginal communities [including] all forms of development" (Nadasdy, 2003:145) is remote.

Political scientists employ the concept of "path dependence" to explain government policy and development of state structures (Pierson, 2004). In this schema, choices and decisions at key historical junctures condition and constrain subsequent policy choices and institutional developments. It is not a determinist interpretation, but it does alert us to the weight of past decisions. And weighty decisions on the part of both the state and aboriginal peoples to enter into comprehensive landclaim agreements (and, inter alia, to accept the boards created under those claims) powerfully condition aboriginal-state relations. Governments, believing claims to be "final" and "settled," are unlikely to welcome attempts to renegotiate critical land and resource provisions. For their part, aboriginal governments and political organizations with settled claims are concerned primarily with ensuring that the state lives up to its commitments in terms of properly implementing their claims and are equally unlikely to initiate attempts at sweeping renegotiation. While they sometimes disagree vigorously with the policies and decisions of federal and territorial governments, northern aboriginal governments and political organizations have become highly institutionalized and in certain ways have become enmeshed in, or adjuncts of, the state. (An important example is the aboriginal groups' nomination or appointment of landclaim board members, with the patronage possibilities this entails.) Thus, in the absence of clearly articulated strategies for replacing the land-claim board regimes, which neither Nasasdy nor Stevenson offers, no serious alternative to these boards seems likely to emerge for some considerable time.

\section{CONCLUSION}

Overall, the evidence, although fragmentary, impressionistic, and sometimes decidedly equivocal, supports the proposition that aboriginal peoples can and do wield significant influence over land and wildlife decisions through the boards established under the northern comprehensive land claims. Land-claim boards exercise substantial power over land and resource decisions, their apparently limited authority notwithstanding. A high proportion of board members are aboriginal, and their direct influence on board decisions is substantial. Boards and board members enjoy extensive independence in their operations and in their decision making, although important constraints on their independence, most notably through Ottawa's appointment prerogative and its funding processes, are evident. TK plays an important role in land-claim board decisions (both wildlife management and environmental regulation); however, although boards have sincerely tried to incorporate TK into all phases of their work, the boards' essentially bureaucratic nature means that these attempts have been only partially successful.

Criticisms of individual boards and the entire board regime abound, but no one proposes a return to the days when aboriginal people were effectively excluded from land and resource decisions made by the federal government. Agreement is all but universal that the land-claim boards offer aboriginal people substantially greater influence over government decisions affecting the land and wildlife than was possible, or even imaginable, under the state system. To be sure, sophisticated critiques have been mounted on land-claim (and other) boards as agents of cultural assimilation, but the critics do not offer much guidance as to how a far-reaching restructuring of the boards and their role within the Canadian state, or their wholesale replacement by a fundamentally different regime, might come about. Current political configurations suggest that the prospects for a resource management regime characterized by genuine aboriginal control displacing the land-claim boards in the foreseeable future are slim.

Thus if "the alternative" is the state management system that largely excluded aboriginal people and their TK, land-claim boards may be judged a success in securing 
aboriginal influence over important land and wildlife decisions. Yet other alternatives that go beyond a vaguely defined ideal regime ("the Almighty") do exist. Feit's assessment that the way forward "must include the continued development of forms of self-management as well as improved forms of state-level wildlife management... [since] in a real and practical sense they are now inseparably interlinked, and in many ways they are necessary to each other" is no less valid today than when it was written in the late 1980s, though it is well to recall an important question he poses: "whether co-management will in the long term come to constitute a form of co-optation and domination, which will weaken self-management and selfgovernance" (Feit, 1988:84-85).

Land-claim boards and the role they play in northern governance continue to evolve, and it is an open question whether, in terms of aboriginal influence, change will represent progress or regress. This paper has demonstrated, however, that to this point the overall record of land-claim boards is positive in promoting and protecting aboriginal interests and worldviews in government policies and decisions relating to wildlife and environmental regulation.

\section{ACKNOWLEDGEMENTS}

This paper is part of a larger project on the operation and influence of the boards established by the land-claim agreements in northern Canada, funded by the Social Sciences and Humanities Research Council of Canada. I wish to record my thanks to the dozens of members, staff, and observers of northern land-claim boards, government officials, and representatives of aboriginal organizations who consented to not-for-attribution interviews with me over the past few years. Special thanks also to the various board staff who answered follow-up questions and provided documents and to Gina Cosentino for her expert research assistance. Finally, the paper benefited substantially from the criticisms and suggestions offered by the referees.

\section{REFERENCES}

BANNON, P., and DUNLOP, W. 1998. Building partnerships in impact assessment: A Canadian approach. Paper presented at the International Association of Impact Assessment, April 1998, Christchurch, New Zealand.

BELL, J. 2005. NPC board asks chairman to quit. Nunatsiaq News, June 10.

BERGER, T.R. 2005. Nunavut land claims agreement implementation contract negotiations for the second planning period 2003-2013: Conciliator's interim report. Ottawa: Indian and Northern Affairs Canada. 42 p. http://www.tunngavik.com/ english/publications.php\#05.

BERKES, F. 1999. Sacred ecology: Traditional ecological knowledge and resource management. Philadelphia: Taylor and Francis.
BINDER, L.N., and HANBIDGE, B. 1993. Aboriginal people and resource management. In: Inglis, J., ed. Traditional ecological knowledge: Concepts and cases. Ottawa: Canadian Museum of Nature. $121-132$.

BRYANT, M. 2005. Burlingame confirmed in job. News/North, May 2.

CBC NEWS. 2005. Empty seats on boards vex Nunavut regulators. October 24. Copy in author's files.

-2006. Women have little say on wildlife boards, Inuit group finds. August 2. www.cbc.ca/canada/north/story/2006/08/02/ hunter-women-boards.html.

CHRISTENSEN, J., and GRANT, M. 2007. How political change paved the way for indigenous knowledge: The Mackenzie Valley Resource Management Act. Arctic 60(2):115-123.

DANLYCHUK, J. 2005. Handley wants action. News/North, May 23.

DONIHEE, J. 2001. Implementing co-management legislation in the Mackenzie Valley. Paper presented at the Canadian Bar Association conference, Aboriginal Governance, 2001 and Beyond, 27-28 April 2001, Yellowknife, Northwest Territories.

DOUBLEDAY, N. 1989. Co-management provisions of the Inuvialuit Final Agreement. In: Pinkerton., E., ed. Co-operative management of local fisheries. Vancouver: UBC Press. 209-227.

FEIT, H.A. 1988. Self-management and state-management: Forms of knowing and managing northern wildlife. In: Freeman, M.M.R., and Carbyn, L.N., eds. Traditional knowledge and renewable resource management in northern regions. Occasional Publication 23. Edmonton: Boreal Institute for Northern Studies. 72-91.

FENGE, T. 1992. Political development and environmental management in northern Canada: The case of the Nunavut agreement. Etudes/Inuit/Studies 16(1-2):115-141.

GALBRAITH, L., BRADSHAW, B., and RUTHERFORD, M.B. 2007. Towards a new supraregulatory approach to environmental assessment in northern Canada. Impact Assessment and Project Appraisal 25(1):27-41.

HOGH, H. 2000. Bowhead whale hunting in Nunavut: A symbol of self-government. In: Dahl, J., Hicks, J., and Jull, P., eds. Nunavut: Inuit regain control of their lands and their lives. Copenhagen: International Work Group for Indigenous Affairs. 196-204.

HUNN, E.S., JOHNSON, D.R., RUSSELL, P.N., and THORNTON, T.F. 2003. Huna Tlingit traditional environmental knowledge and the management of a 'wilderness' park. Current Anthropology 44(Supp.):S79-S103.

HUNSLEY, C. 2005. Water Board gets hard as ice. News/North, June 20.

KENDRICK, A. 2000. Community perceptions of the BeverlyQamanirjuaq Caribou Management Board. Canadian Journal of Native Studies 20(1):1-33.

MENZIES, C.R., and BUTLER, C. 2006. Introduction: Understanding ecological knowledge. In: Menzies, C.R., ed. Traditional ecological knowledge and natural resource management. Lincoln and London: University of Nebraska Press. 1-20.

MVEIRB (MACKENZIE VALLEY ENVIRONMENTAL IMPACT REVIEW BOARD). 2004. Report of environmental 
assessment and reasons for decision on the New Shoshoni Ventures preliminary diamond exploration in Drybones Bay. Yellowknife: February 10. http://www.mveirb.nt.ca/registry/ index.php.

. 2007. Report of environmental assessment and reasons for decision on Ur Energy Inc Screech Lake uranium exploration project(EA 0607-003). Yellowknife: May 7. http://www.mveirb. nt.ca/registry/index.php.

NADASDY, P. 2003. Hunters and bureaucrats: Power, knowledge and aboriginal-state relations in the southwest Yukon. Vancouver: UBC Press. 312 p.

- 2005. The anti-politics of TEK: The institutionalization of co-management discourse and practice. Anthropologica 47(2):215-232.

NATCHER, D.C., DAVIS, S., and HICKEY, C.G. 2005. Comanagement: Managing relationships, not resources. Human Organization 64(3):240-250.

NTI (NUNAVUT TUNNGAVIK INCORPORATED). 2005. Call for nomination [Advertisement]. Nunatsiaq News, April 29.

PIERSON, P. 2004. Increasing returns, path dependence and the study of politics. American Political Science Review 94(2): $251-267$.

RESOURCE FUTURES INTERNATIONAL. 1993. Inuvialuit Final Agreement environment and wildlife provisions: An implementation evaluation prepared for the joint IFA Evaluation Advisory Committee under the auspices of Indian and Northern Affairs Canada. Ottawa: RFI. Copy in author's files.

SIMMONS, N.M., and NETRO, G.1995. Yukon land claims and wildlife management: The cutting edge. In: Geist, V., and McTaggart-Cowan, I., eds. Wildlife conservation policy. Calgary: Detselig Enterprises Ltd. 161-173.

SPAK, S. 2005. The position of indigenous knowledge in Canadian co-management organizations. Anthropologica 47(2):233-246.
STAPLES, L. 1995. The Inuvialuit final agreement: Implementing its land, resource, and environmental regimes. Report prepared for the Royal Commission on Aboriginal Peoples (RCAP). Ottawa: Indian and Northern Affairs Canada.

STEVENSON, M. 2004. Decolonizing co-management in northern Canada. Cultural Survival Quarterly 28(1):68-72.

- 2006. The possibility of difference: Rethinking comanagement. Human Organization 65(2):167-180.

TRESEDER, L., and HONDA-McNEIL, J. 1999. The evolution and status of wildlife co-management in Canada. In: Treseder, L., ed. Northern eden: Community-based wildlife management in Canada. Edmonton: Canadian Circumpolar Institute. 5-20.

USHER, P. 1993. The Beverly-Kaminuriak Caribou Management Board: An experience in co-management. In: Inglis, J., ed. Traditional ecological knowledge: Concepts and cases. Ottawa: Canadian Museum of Nature. 111-120.

. 1996. Contemporary aboriginal land, resource, and environment regimes: Origins, problems, prospects. Report prepared for the Royal Commission on Aboriginal Peoples. Ottawa: Indian and Northern Affairs Canada.

- 2003. Environment, race and nation reconsidered: Reflections on aboriginal land claims in Canada. The Canadian Geographer 27(4):365-382.

VERTES, L., CONNELlY, D., and KNOTT, B. 1999. Implementation of the Nunavut Land Claims Agreement: An independent 5-year review, 1993 to 1998. Yellowknife: Ile Royale Enterprises.

WHITE, G. 2002. Treaty federalism in northern Canada: Aboriginalgovernment land claims boards. Publius: The Journal of Federalism 32(3):89-114.

. 2006. Cultures in collision: Traditional knowledge and Euro-Canadian governance processes in northern land-claim boards. Arctic 59(4):401-414. 